Louisiana State University

LSU Digital Commons

$8-1-2010$

\title{
Metabolic preconditioning of cells with AICAR-riboside: Improved cryopreservation and cell-type specific impacts on energetics and proliferation
}

\author{
Michael A. Menze \\ Louisiana State University \\ Nilay Chakraborty \\ Massachusetts General Hospital \\ Matthew Clavenna \\ Louisiana State University \\ Mitali Banerjee \\ Massachusetts General Hospital \\ Xiang Hong Liu \\ Massachusetts General Hospital
}

See next page for additional authors

Follow this and additional works at: https://digitalcommons.Isu.edu/biosci_pubs

\begin{abstract}
Recommended Citation
Menze, M., Chakraborty, N., Clavenna, M., Banerjee, M., Liu, X., Toner, M., \& Hand, S. (2010). Metabolic preconditioning of cells with AICAR-riboside: Improved cryopreservation and cell-type specific impacts on energetics and proliferation. Cryobiology, 61 (1), 79-88. https://doi.org/10.1016/j.cryobiol.2010.05.004
\end{abstract}

This Article is brought to you for free and open access by the Department of Biological Sciences at LSU Digital Commons. It has been accepted for inclusion in Faculty Publications by an authorized administrator of LSU Digital Commons. For more information, please contact ir@lsu.edu. 


\section{Authors}

Michael A. Menze, Nilay Chakraborty, Matthew Clavenna, Mitali Banerjee, Xiang Hong Liu, Mehmet Toner, and Steven C. Hand 


\title{
Metabolic Preconditioning of Cells with AICAR-Riboside: Improved Cryopreservation and Cell-Type Specific Impacts on Energetics and Proliferation
}

\author{
Michael A. Menze ${ }^{\star}$, Nilay Chakraborty§, Matthew Clavenna ${ }^{\star}$, Mitali Banerjee§, Xiang-Hong \\ Liu§, Mehmet Toner§, and Steven C. Hand ${ }^{\star}$ \\ "Division of Cellular, Developmental, and Integrative Biology, Department of Biological Sciences, \\ Louisiana State University, Baton Rouge, LA, 70803, USA \\ $\S$ Center for Engineering in Medicine and Surgical Services, Massachusetts General Hospital, \\ Harvard Medical School and Shriners Hospitals for Children, 51 Blossom Street, Boston, MA \\ 02114, USA
}

\begin{abstract}
In species whose evolutionary history has provided natural tolerance to dehydration and freezing, metabolic depression is often a pre-requisite for survival. We tested the hypothesis that preconditioning of mammalian cells with 5-aminoimidazole-4-carboxamide-1-b-D-ribofuranoside (AICAR) to achieve metabolic depression will promote greater survivorship during cryopreservation. AICAR is used extensively to stimulate AMP-activated protein kinase (AMPK), which can result in downregulation of biosynthetic processes. We showed that the metabolic interconversion of AICAR was cell-type dependent. Accumulation of 5-aminoimidazole-4carboxamide-1b-D-ribofuranosyl-5'-monophosphate (ZMP), as well as other metabolites that possess multiple phosphates (i.e., ZDP, ZTP), varied approximately 3.5-fold across the cell lines tested. AICAR treatment also significantly influenced the concentrations of cellular adenylates (ATP, ADP, AMP). Depression of cell metabolism and proliferation with AICAR treatment differed among cell lines. Proliferation for a given cell line was negatively correlated with the fold-increase achieved in the 'effective adenylate ratio' ([AMP]+[ZMP])/[ATP]) after AICAR treatment. Metabolic preconditioning with AICAR promoted a significant increase in viability post-freezing in J774.A1 macrophages, HepG2/C3A cells and primary hepatocytes but not in NIH/ $3 \mathrm{~T} 3$ fibroblasts or OMK cells. The effect of AICAR on viability after freezing was positively correlated $\left(\mathrm{r}^{2}=0.94\right)$ with the fold-increase in the 'effective adenylate ratio'. Thus for each cell line, the greater the depression of metabolism and proliferation due to preconditioning with AICAR, the greater was the survivorship post-freezing.
\end{abstract}

\section{Keywords}

AICAR; adenylate levels; ATP; metabolism; cell stasis; biostabilization

(C) 2010 Elsevier Inc. All rights reserved.

Address for reprint requests and other correspondence: M. A. Menze, Dept. of Biological Sciences, Louisiana State University, 202 Life Sciences Bldg., Baton Rouge, LA, 70803. Tel.: 225-578-1552; Fax: 225-578-2597;menze@1su.edu.

Publisher's Disclaimer: This is a PDF file of an unedited manuscript that has been accepted for publication. As a service to our customers we are providing this early version of the manuscript. The manuscript will undergo copyediting, typesetting, and review of the resulting proof before it is published in its final citable form. Please note that during the production process errors may be discovered which could affect the content, and all legal disclaimers that apply to the journal pertain. 


\section{INTRODUCTION}

The ability of an animal to arrest development and metabolism before when faced with environmental challenges like desiccation, anoxia, and freezing improves the survival of many species [1-3]. By considering this lesson from nature, one key prediction that emerges is that the placement of mammalian cells into stasis will foster greater survival of cells when exposed to stabilization methods like dehydration, lyophilization, or cryopreservation. This prediction is based on our understanding of the biological principles and criteria that underlie naturally occurring states of dormancy, particularly diapause [4,5]. When animals enter diapause, normal developmental programs are interrupted. Catabolic and anabolic processes are downregulated in a coordinated fashion, which minimizes imbalances in cellular processes that could lead to pathological conditions. In this regulated state of stasis, diapausing animals are more tolerant of environmental stresses like anoxia and dehydration $[2,3,6,7]$. Consequently, it is reasonable to hypothesize that mammalian cells, which normally do not experience drying or freezing, may also benefit from preconditioning. In the present study, we show for the first time that metabolic preconditioning improves cell viability after freezing. Specifically, pre-treatment with 5-aminoimidazole-4-carboxamide-1b-D-ribofuranoside $(\mathrm{AICAR})^{1}$ promotes a significant increase in survivorship post-freezing.

AICAR has the potential to mimic a number of the metabolic features associated with diapause. Most of its effects on cell metabolism are exerted by its phosphorylated form ZMP, which activates the enzyme AMP-activated protein kinase (EC2.7.11.27, AMPK) $[8,9]$. AMPK is part of an ultrasensitive system for monitoring cellular energy changes and can be considered a metabolic "fuel gauge" [10]. Under optimal physiological conditions, the AMP:ATP ratio is maintained at approximately 0.01 [11]. An increase in AMP/ATP activates AMPK by four different mechanisms: 1) allosteric activation of the enzyme by binding to AMP, 2) allosteric activation of the upstream AMPK kinase LKB1, which increases AMPK activity by phosphorylation of AMPK, 3) a decreased affinity of the liganded AMPK for the protein phosphatase, and 4) an increased affinity of the liganded AMPK to LKB1 [12-14]. The activation of the AMPK cascade leads to several metabolic responses: an inhibition of anabolic pathways such as fatty acid synthesis, lipogenesis, and cell proliferation, and conversely to an activation of selected catabolic pathways such as fatty acid oxidation and glucose uptake. Furthermore, increased AMPK activity seems to decrease or increase apoptosis depending on the experimental model $[15,16]$.

A key feature that contributes to the popularity of AICAR is its ability to cross the cell membrane through the nucleoside transporter [17]. After uptake into the cell, AICAR is phosphorylated by adenosine kinase to form the membrane impermeable compound ZMP [18], which enters the nucleotide pool before the IMP branch point [19]. ZMP mimics the multiple effects of AMP on AMPK, which include allosteric activation and activation of the upstream kinase LKB1 [8,9,20-22]. Cell-type specific differences in response to AICAR have been reported [23]. Many investigators who use AICAR to activate AMPK do not verify rigorously the conversion of AICAR to ZMP, nor do they optimize its concentration and exposure time for maximum effect. Our results demonstrate major differences among cell types in the ability to metabolize AICAR, in the accumulation of di- and triphosphorylated forms of the compound, and in subsequent effects on cell function. Thus, the common practice of ascribing the influence of AICAR exclusively to AMPK activation,

\footnotetext{
${ }^{1}$ In this paper, we refer to the membrane permeable, non-phosphorylated form of this analogue as AICAR, and the phosphorylated compound as ZMP, based on the nomenclature of Hardy et al. [12]. In some references and databases, the phosphorylated compound is designated as AICAR [e.g., http://www.genome.ad.jp; cpd: C04677; GenomeNet (Bioinformatics Center, Institute for Chemical research, Kyoto University)].
} 
without first completing a thorough analysis of its metabolic impact on the chosen cell type, is called into question.

\section{MATERIALS AND METHODS}

\section{Chemicals}

Tetrabutylammonium bisulfate and 2-deoxy-D-glucose were purchased from Sigma-Aldrich (St. Louise, MO). Chemicals for HPLC analysis, including acetonitrile and potassium phosphates, were obtained from Fisher Scientific (Pittsburgh, PA). AICAR and ZMP were purchased from Toronto Research Chemicals Inc. (North York, ON, Canada). Water for solution preparation was purified with a Milli-Q Reagent Water System (Millipore, Billerica, MA).

\section{Cells}

All four cell lines were obtained from ATCC (Manassas, VA) and grown in $75 \mathrm{~cm}^{2}$ cell culture flasks (Corning Incorporated, Corning, NY). J774A.1 macrophages and NIH/3T3 fibroblasts were cultured in Dulbecco's modified Eagle's medium (DMEM, without sodium pyruvate) that was supplemented with $10 \%$ fetal bovine serum, 100 units/ml penicillin, 100 $\mu \mathrm{g} / \mathrm{ml}$ streptomycin and $2 \mathrm{mM}$ glutamine (all from Invitrogen, Grand Islands, NY). These cells were maintained in a humidified atmosphere of $10 \% \mathrm{CO}_{2}$ and $90 \%$ air at $37{ }^{\circ} \mathrm{C}$. HepG2/C3A cells were cultured in Minimum Essential Medium (MEM) with 2 mM Lglutamine and Earle's salts, supplemented with $0.1 \mathrm{mM}$ non-essential amino acids, $1.0 \mathrm{mM}$ sodium pyruvate, $10 \%$ fetal bovine serum, 100 units $/ \mathrm{ml}$ penicillin, and $100 \mu \mathrm{g} / \mathrm{ml}$ streptomycin. OMK cells were cultured in Minimum Essential Medium, Alpha (AMEM) (Mediatech, Herndon, VA) that was supplemented as for $\mathrm{HepG} 2 / \mathrm{C} 3 \mathrm{~A}$ cells. These two cell lines were maintained in a humidified atmosphere of $5 \% \mathrm{CO}_{2}$ and $95 \%$ air at $37^{\circ} \mathrm{C}$. Culture medium was renewed every 2 - 4 days for all cell lines.

To subculture J774A.1 macrophages, cells were dislodged with a scraper, counted with a hemocytometer (Hausser and Son, Philadelphia, PN), and plated at a concentration of $0.5 \times$ $10^{6}$ cells per flask. OMK, HepG2/C3A, and NIH/3T3 cells were removed using $0.25 \%$ trypsin plus $1 \mathrm{mM}$ EDTA in PBS (Invitrogen) and subcultured at the same starting density as J774A. 1 cells. NIH/3T3 cells were subcultured before reaching 90\% confluency. For calorespirometry (see below), cells were grown on Cytodex 1 micro-carrier beads (SigmaAldrich, St. Louise, MO) in a stirred culture system. To ensure that the cell cultures were mycoplasma free, the MycoAlert Mycoplasma Detection Kit (Cambrex Bio Science Rockland, Inc., Rockland, ME) was used periodically.

\section{Hepatocyte isolation and culture}

Hepatocyte culture medium consisted of DMEM supplemented with $10 \%$ fetal bovine serum, $7 \mathrm{ng} / \mathrm{ml}$ glucagon (Bedford Laboratories, Bedford, $\mathrm{OH}$ ), $7.5 \mathrm{mg} / \mathrm{ml}$ hydrocortisone (Pharmacia Corporation, Kalamazoo, MI), $0.5 \mathrm{U} / \mathrm{ml}$ insulin (Eli Lilly, Indianapolis, IN), 20 $\mathrm{ng} / \mathrm{ml}$ epidermal growth factor (Sigma Chemical Co., St. Louis, MO), $200 \mathrm{U} / \mathrm{ml}$ penicillin, and $200 \mathrm{mg} / \mathrm{ml}$ streptomycin. Hepatocytes were obtained from adult female Lewis rats (150-200g; Charles River Laboratories, Boston, MA). A two-step procedure for collagenase perfusion, modified from Seglen [26], was used for hepatocyte isolation as described previously [27-29]. Typically, $200-300$ million hepatocytes were obtained using all lobes of the liver from one rat, and cell viability was $>90 \%$ as determined by trypan blue exclusion. Tissue culture dishes ( $60 \mathrm{~mm}$ diameter) were coated with a solution of type I rat tail collagen $(0.11 \mathrm{mg} / \mathrm{ml})$ for $30 \mathrm{~min}$ at $37^{\circ} \mathrm{C}$. After rinsing the dishes twice with phosphate buffered saline (PBS), 1-3 million hepatocytes were seeded in $2 \mathrm{ml}$ culture mediumequilibrated with $10 \% \mathrm{CO}_{2}$ and $90 \%$ air at $37{ }^{\circ} \mathrm{C}$. 


\section{Cell viability and activity assays}

Cells were grown in the presence and absence of AICAR and viability assessed by two methods. Cells were counted at various time points with a hemocytometer after diluting the sample 1:1 with $0.4 \%$ trypan blue solution (Sigma, St. Louise, MO). Alternatively, the metabolic activity of the cells was monitored with alamarBlue ${ }^{\mathrm{TM}}$ (BioSource International, Inc., Camarillo, CA). A working solution of alamarBlue ${ }^{\mathrm{TM}}$ was prepared by diluting the commercial stock solution 10-fold with culture medium without phenol red. Then $2 \mathrm{ml}$ of this working solution was added to each well of a 12 well Nunclun ${ }^{\mathrm{TM}}$ multidish (Fischer Scientific, Pittsburg, PA). After adding 20,000 to 40,000 cells to each well, the absorbance at $\lambda=570 \mathrm{~nm}$ and $\lambda=600 \mathrm{~nm}$ was measured with a micro plate reader (Spectra $\max _{\text {Plus, }}$ Pl Molecular Devices, Sunnyvale, CA) at selected time points. The percent of reduced alamarBlue ${ }^{\mathrm{TM}}(\mathrm{RA} \%)$ was calculated as: $\mathrm{RA} \%=\left[\mathrm{A}_{570}-\mathrm{A}_{600} \cdot \mathrm{R}_{\mathrm{o}}\right] \cdot 100$, where $\mathrm{A}_{570}$ and $\mathrm{A}_{600}$ are the absorbances at wavelengths of $570 \mathrm{~nm}$ and $600 \mathrm{~nm}$ after subtracting the absorbance of culture medium without alamarBlue ${ }^{\mathrm{TM}}$. $\mathrm{R}_{\mathrm{o}}$ is the ratio of $\mathrm{A}_{570}$ to $\mathrm{A}_{600}$ for culture medium containing $10 \%$ alamarBlue ${ }^{\mathrm{TM}}$.

All cell types were plated at a density of $2 \times 10^{6}$ cells and left untreated for $24 \mathrm{~h}$. Media was exchanged and experimental plates were exposed to $1 \mathrm{mM}$ AICAR for $24 \mathrm{~h}$. Cells grown in culture dishes were washed 4 times with $25 \mathrm{ml}$ of ice-cold PBS, and analysis of the final wash solution by HPLC confirmed the absence of residual AICAR. Cellular protein was quantified using a modified Lowry assay according to Peterson [30] with BSA as the standard.

\section{High performance liquid chromatography (HPLC) of nucleotides and analogues}

Cell culture plates were placed on ice, and cells were removed using a cell scraper. Acid soluble extracts of cell suspensions were prepared as previously described [31] by adding ice-cold $70 \%$ perchloric acid to a final concentration of $7 \%(\mathrm{w} / \mathrm{v})$. Acid insoluble fractions were removed by centrifugation for $10 \mathrm{~min}$ at $13,000 \mathrm{~g}$ and $4{ }^{\circ} \mathrm{C}$ (Eppendorf Centrifuge 5417R, Fischer Scientific, Pittsburg, PA). Extracts were neutralized with ice-cold $5 \mathrm{M}$ $\mathrm{K}_{2} \mathrm{CO}_{3}$ and stored at $-80{ }^{\circ} \mathrm{C}$ until analyzed. Prior to the HPLC analysis, the potassium perchlorate precipitate was removed by centrifugation as above. Analyses were performed using a Dionex HPLC system (Dionex, Sunnyvale, CA), which included a PDA-100 photodiode array detector, GP-50 gradient pump, AS50 auto-sampler and AS50 thermal compartment. Samples were held at $4{ }^{\circ} \mathrm{C}$ in the auto-sampler and applied to a $4.6 \mathrm{~mm} \times 25$ $\mathrm{cm}$ reversed phase column (Synergy $4 \mu$ Hydro RP 80A, Phenomenex, Torrance, CA). The samples were eluted isocratically for $15 \mathrm{~min}$ at a flow rate of $1 \mathrm{ml} / \mathrm{min}$ at $30^{\circ} \mathrm{C}$ with a starting buffer of $50 \mathrm{mM} \mathrm{K} 2 \mathrm{HPO}_{4} / \mathrm{KH}_{2} \mathrm{PO}_{4}(\mathrm{pH} \mathrm{5.8)}$ that contained $10 \mathrm{mM}$ tetrabutylammonium bisulfate. Then a linear gradient of acetonitrile (0\% to $25 \%$ in starting buffer) was applied over $40 \mathrm{~min}$. The absorbance of the effluent was monitored with a photodiode array detector at wavelengths from $\lambda=190 \mathrm{~nm}$ to $\lambda=390 \mathrm{~nm}$. Peaks were identified by comparison with retention times of standards, as well as by analyses of peak spectra from a recorded 3d-field with Chromeleon ${ }^{\mathrm{TM}}$ software (Dionex, Sunnyvale, CA). Concentration of nucleotides was determined from measurement of peak area at $\lambda=260 \mathrm{~nm}$. Calibration curves were linear over the range assayed.

\section{Microcalorimetry and respirometry}

To assess the metabolic status of NIH/3T3 mouse fibroblasts, we employed simultaneous microcalorimetry and respirometry [32-34]. The simultaneous measurement of heat flux and oxygen flux (calorespirometry) not only yields baseline estimates of energy flow but also can be used to non-invasively evaluate whether or not anaerobic pathways are contributing to overall cellular metabolism. If isolated cells are incubated under conditions that promote a fully aerobic metabolism, then the experimentally determined ratio of kilojoules of heat 
dissipated per mole of oxygen consumed (i.e., the calorimetric-respirometric ratio, or CR ratio) should fall within the range of the theoretical oxycaloric equivalent $(-430$ to $-480 \mathrm{~kJ}$ mol $\mathrm{O}_{2}^{-1}$; [32]). However, if the $\mathrm{CR}$ ratio is markedly higher (i.e. more negative) than -430 to $-480 \mathrm{~kJ} \mathrm{~mol} \mathrm{O}_{2}{ }^{-1}$, then an anaerobic contribution to energy production is indicated.

The LKB 2277 thermal activity monitor (Bromma, Sweden) was used to measure the heat dissipation of cells in suspension. A $4 \mathrm{ml}$ sealed ampoule that contained $2.7 \mathrm{ml}$ of water was used as a reference vessel. Static and dynamic calibrations against water in both ampoules were performed before the heat signal was measured. For the biological experiments, water in the sample ampoule was replaced with $2.7 \mathrm{ml}$ of cell suspension. This total suspension contained between 130,000 and 250,000 cells in culture medium equilibrated with $10 \% \mathrm{CO}_{2}$ and $90 \%$ air. All calorimetric measurements were performed at $37^{\circ} \mathrm{C}$. A $2 \mathrm{~h}$ period for thermal equilibration was allowed after the ampoule was lowered into the calorimeter, and then the heat flow $(\mu \mathrm{W})$ was recorded for $20 \mathrm{~h}$. Under experimental conditions promoting cell proliferation, the heat flux increased continuously. In these cases, the heat flux was corrected for the increase in cell number by extrapolation back to the cell count at time zero.

\section{Freezing of cell lines and primary hepatocytes}

All cell lines (HepG2/C3A, J774.A1, NIH/3T3, and OMK) were agitated with a vortex mixer for $30 \mathrm{~min}$ at $30{ }^{\circ} \mathrm{C}$ with $200 \mathrm{mM}$ 3-O-Methyl-D-gluco-pyranose (3-OMG) dissolved in cell culture medium in order to preload this cryoprotectant. Control cells received no AICAR exposure, and experimental cells were pretreated with $1 \mathrm{mM}$ AICAR for $24 \mathrm{~h}$ prior to loading of 3-OMG. Cells were then sedimented by centrifugation (10 min at 10,000 $\mathrm{g}$ and $4{ }^{\circ} \mathrm{C}$ ), and the medium was replaced with Hypo Thermosol FRS (Biolife Solutions, Bothell, WA) that also contained $200 \mathrm{mM} 3$-OMG. Cells were chilled in a controlled-rate freezer (1 ${ }^{\circ} \mathrm{C} /$ min, seeding at $-6{ }^{\circ} \mathrm{C}$; Cryologic Pty, Mulgrave, Australia) to $-80{ }^{\circ} \mathrm{C}$ and stored in liquid nitrogen at $-196{ }^{\circ} \mathrm{C}$ for $24 \mathrm{~h}$. After this time, the cells were thawed rapidly at $37{ }^{\circ} \mathrm{C}$ and plated in cell culture medium. Cell viability was determined by trypan blue exclusion 24 $\mathrm{h}$ after plating and expressed as a percentage of cells that were present before freezing. Freshly isolated hepatocytes $\left(2 \times 10^{6}\right.$ cells $\left./ \mathrm{ml}\right)$ were incubated for $60 \mathrm{~min}$ at $37^{\circ} \mathrm{C}$ with 200 $\mathrm{mM} 3-\mathrm{OMG}$ dissolved in cell culture medium, with or without $0.5 \mathrm{mM}$ AICAR. After the incubation, cells were sedimented by centrifugation $\left(10 \mathrm{~min}\right.$ at $10,000 \mathrm{~g}$ and $\left.4{ }^{\circ} \mathrm{C}\right)$, and the medium was replaced with Hypo Thermosol FRS that also contained $200 \mathrm{mM} 3-\mathrm{OMG}$. Cells were chilled in the controlled rate freezer $\left(0.5^{\circ} \mathrm{C} / \mathrm{min}\right.$, seeding at $\left.-10{ }^{\circ} \mathrm{C}\right)$ to $-80{ }^{\circ} \mathrm{C}$ and stored in liquid nitrogen at $-196^{\circ} \mathrm{C}$ for $24 \mathrm{~h}$. After this time, the cells were thawed rapidly at $37^{\circ} \mathrm{C}$ and plated on collagen coated plates in cell culture medium. Cell viability was determined as above.

\section{Statistical analyses}

Statistical significance between groups was evaluated with a one-way ANOVA on ranks followed by the Student-Newman-Keuls Method (for groups with equal sample sizes) or Dunn's test (for groups with unequal sample sizes) for all pair-wise comparison of means, $\mathrm{P}$ $>0.05$, with SigmaPlot $\odot$ for Windows Version 11.0 (SPSS Inc., Chicago, IL). Error propagation was calculated after the method of Doerfel [35].

\section{RESULTS}

\section{Metabolic profiles of NIH/3T3 mouse fibroblasts}

In order to measure the impact of acute exposure of AICAR on NIH/3T3 mouse fibroblast, we characterized cells grown on Cytodex 1 microcarrier beads. Evaluating the metabolic poise of cells (i.e., the relative contributions of anaerobic and aerobic metabolism) is important for determining whether culture conditions are optimal for maintaining a fully 
aerobic state under our treatment conditions. First, total heat dissipation rate was measured for control fibroblasts, and these values varied depending on the cell density on the carrier beads. At low cell density (about $18 \mathrm{~h}$ after seeding), the heat output was $-18.4 \pm 1.6 \mu \mathrm{W}$ per million cells ( $n=5, \pm \mathrm{SE}$ ), and this value increased to $-28.2 \pm 1.9 \mu \mathrm{W}$ per million cells $(n=5, \pm \mathrm{SE})$ after entering the exponential growth phase. In cultures that reached a high density and therefore exited the exponential growth phase, heat dissipation decreased to $-14.9 \pm 0.7 \mu \mathrm{W}$ per million cells $(n=4, \pm \mathrm{SE}$ ) (Fig. 1). Second, during exponential growth of the culture there was an increase in the CR ratio of cells, which suggests that the contribution of anaerobic pathways to overall metabolic rate was elevated (Fig. 1). As the culture became contact inhibited (confluence $>80 \%$ ), the $\mathrm{CR}$ ratio returned to a value statistically the same as the theoretical oxycaloric equivalent for mixed substrate respiration $\left(-450 \mathrm{~kJ} / \mathrm{mol} \mathrm{O}_{2}\right)(n=3 ; \mathrm{P}>0.05)$. Exposure of cells during exponential growth (confluence $~ 50 \%$ ) to $2 \mathrm{mM}$ AICAR for $1 \mathrm{~h}$ induced a drop in heat dissipation by about $20 \%$ with respect to the control (Fig. 2). A further reduction can be observed by adding $20 \mathrm{mM}$ of the glycolytic inhibitor 2-deoxy-D-glucose (2-DG). A combination of AICAR and 2-DG led to a $50 \%$ depression in energy flow (Fig. 2).

\section{Depression of cell proliferation and alamarBlue ${ }^{\mathrm{TM}}$ reduction by AICAR}

A convenient way to assess metabolic activity and proliferation of cells is by measuring the reduction of the redox-indicator alamarBlue ${ }^{\mathrm{TM}}$. Exposure of NIH/3T3 cells to $2 \mathrm{mM}$ AICAR for $1 \mathrm{~h}$ inhibited the reduction of alamarBlue ${ }^{\mathrm{TM}}$ by about $23 \%$ after $24 \mathrm{~h}$ and by about $15 \%$ after $48 \mathrm{~h}$ (Fig. 3A). However, the impact on proliferation was far less pronounced. Cell counts did not reveal any significant reduction in cell proliferation $24 \mathrm{~h}$ after transient exposure to AICAR, and only a modest reduction of about $10 \%$ was observed after $48 \mathrm{~h}$ (Fig. 3B).

One goal of the present study was to induce a stasis-like phenotype by pharmacological intervention in an attempt to increase cell viability after cryopreservation. Because of the weak correlation between alamarBlue ${ }^{\mathrm{TM}}$ reduction and cellular proliferation observed in $\mathrm{NIH} / 3 \mathrm{~T} 3$ cells after short-term AICAR treatment, we decided to monitor proliferation of $\mathrm{NIH} / 3 \mathrm{~T} 3$ fibroblasts and several other cell lines after long-term $(24 \mathrm{~h})$ exposure to AICAR. Continuous exposure to $1 \mathrm{mM}$ AICAR for $24 \mathrm{~h}$ reduced proliferation of NIH/3T3 cells by about $40 \%$ (Fig. 4). Surprisingly, we found that the effect of AICAR on cell proliferation varied greatly between cell lines. After $24 \mathrm{~h}$ exposure to AICAR, proliferation of owlmonkey kidney cells (OMK) was $90 \% \pm 6 \%$ of untreated control cells, and proliferation J774 mouse macrophage cells was $33 \% \pm 4 \%$ of controls ( \pm SE, $n=5-7$ ) (Fig.4). To investigate whether or not these AICAR-induced differences in proliferation were the result of differential capacities among cell types for AICAR interconversion and/or other impacts on cellular nucleotide pools, we analyzed cell extracts with HPLC.

\section{Impact of AICAR on adenylates and adenylate analogues in cell lines and primary hepatocytes}

Figure 5 shows a representative HPLC chromatogram of an extract from NIH/3T3 cells that were exposed to $1 \mathrm{mM}$ AICAR for $24 \mathrm{~h}$. All compounds of interest exhibited baseline separation by this technique and a signal-to-noise ratio greater than 20:1. Our analyses not only revealed high intracellular concentrations of AICAR and ZMP but also large accumulations of the multi-phosphorylated compounds ZDP and ZTP.

All cell lines investigated showed some capacity to synthesize ZMP from AICAR, but the amount of ZMP accumulated after $24 \mathrm{~h}$ of $1 \mathrm{mM}$ AICAR exposure varied significantly among cell types (Table 1). In contrast to all other cell types, the OMK cells did not accumulate detectable levels of ZDP or ZTP. For all cells except NIH/3T3 fibroblasts, 
AICAR exposure had a significant impact on the steady-state concentrations of ATP, ADP and AMP. The most dramatic effect was seen with primary hepatocytes, which showed an $80 \%$ drop in ATP levels after exposure to $1 \mathrm{mM}$ AICAR. These cells were very sensitive to the drug. Hepatocyte morphology was substantially affected after $24 \mathrm{~h}$ of incubation (data not shown), and viability was eventually compromised (a noticeable number of dead cells were washed from the plates prior to HPLC analyses). A striking difference was observed between primary hepatocytes and the hepatocellular carcinoma cell line HepG2/C3A. After exposure of HepG2/C3A cells to $1 \mathrm{mM}$ AICAR, ATP levels actually increased from $24.09 \pm$ 2.02 to $35.90 \pm 3.66 \mathrm{nmol}$ per $\mathrm{mg}$ protein $(n=4-5, \pm \mathrm{SD})$ (Table 1$)$.

\section{Impact of AICAR incubation on viability post-freezing}

To test whether or not metabolic preconditioning with AICAR improves survival after cryopreservation, we exposed the four cell lines (J774.A1, HepG2/C3A, NIH/3T3, and OMK) for $24 \mathrm{~h}$ to $1 \mathrm{mM}$ AICAR, a dose previously determined to be tolerated by these cells. This treatment impacted the 'effective adenylate ratio' (Table 1) and significantly inhibited proliferation rates of J774.A1, HepG2/C3A and NIH/3T3 cells (Fig. 4). For these metabolic preconditioning studies with AICAR, we also added a cryoprotectant (3-OMG) that has been shown to improve viability in mammalian cells after cryopreservation. It has been shown that the non-metabolizable sugar 3-OMG is readily loaded into cells via the glucose transporter and acts as a non-toxic cryoprotectant [36,45]. Thus, any increase or decrease in cell viability due to AICAR exposure could be readily detected against the background of freeze tolerance promoted by 3 -OMG. We found that the cryoprotective effect of 3-OMG (200 mM) differed among cell lines (3\% - 20\% viability after freezing, Fig. 6 ), and that cell lines with a large reduction in proliferation after exposure to AICAR (Fig. 4) also showed highly significant improvements in viability after cryopreservation (Fig. 6). For example, the viability of J774.A1 cells increased over 4-fold from 7.8\% $\pm 0.6 \%$ with 3OMG alone to $33 \% \pm 1.5 \%(n=9, \pm \mathrm{SE})$ after pre-treatment with AICAR.

To evaluate whether or not metabolic preconditioning with AICAR also can improve survival during cryopreservation of primary hepatocytes, we limited the exposure of these cells to the highest dose that was well tolerated. Our results with a wide range of concentrations $(0.1-2.5 \mathrm{mM}$ for $1 \mathrm{~h})$ revealed that AICAR concentrations higher than 0.5 $\mathrm{mM}$ led to a change in cell morphology and a decrease in viability of primary cells, as assessed $24 \mathrm{~h}$ post exposure (data not shown). In support of these findings, Guigas et al. [37] showed that $0.5 \mathrm{mM}$ AICAR promoted maximal activation of AMPK in primary rat hepatocytes after $30 \mathrm{~min}$. Control cells exposed to $200 \mathrm{mM} 3-\mathrm{OMG}$ for $1 \mathrm{~h}$ and frozen in Hypo Thermosol FRS (supplemented with $200 \mathrm{mM} 3-\mathrm{OMG}$ ) exhibited a viability of 39.5\% $\pm 4.0 \%$ ( \pm SE, $n=3$ ) after thawing. Exposure of experimental cells to $200 \mathrm{mM} 3-\mathrm{OMG}$ plus $0.5 \mathrm{mM}$ AICAR for $1 \mathrm{~h}$ significantly increased the viability $(\mathrm{P}<0.05)$ over $3-\mathrm{OMG}$ alone (Fig. 7).

\section{DISCUSSION}

The ability to increase the effective steady-state ratio of AMP to ATP in cells provides an opportunity to evaluate the impact of this change on rates of metabolism and cellular proliferation. In natural states of cellular stasis like diapause (a dormant state entered under normoxia, euthermia and full hydration) and anoxia-induced quiescence, a repeated theme is that the AMP:ATP ratio is elevated and tightly correlated with the arrest of metabolism [2,38,42-44]. A high AMP:ATP ratio activates AMPK, which serves to conserve cellular energy stores [10]. Thus, we predicted that the AMPK cascade could be exploited for preconditioning mammalian cells. As shown in this study, the induction of a stasis-like phenotype improved cell viability during cryopreservation. 
In addition to quantifying the improved viability with AICAR treatment, we employed several methods to monitor AICAR-mediated depression of cell metabolism. Calorimetry revealed that the overall energy flow of $\mathrm{NIH} / 3 \mathrm{~T} 3$ cells depends on the cell density. As expected the highest heat output was found for cells that were measured during their exponential growth phase, and all following studies were conducted on cells in this phase. A transient exposure to $2 \mathrm{mM}$ AICAR leads to a $20 \%$ reduction in energy flow of NIH/3T3 cells measured as an acute decrease in heat dissipation. This value correlates well with the $23 \%$ depression in alamarBlue ${ }^{\mathrm{TM}}$ reduction. A further reduction in heat dissipation to about $50 \%$ of control was observed after addition of $20 \mathrm{mM}$ 2-deoxy-D-glucose (2-DG). 2-DG crosses the cell membrane via the glucose transporter and is phosphorylated by hexokinase (EC 2.7.1.1) to 2-deoxy-D-glucose-6-phosphate (2-DGP), which accumulates inside the cell [39]. 2-DGP inhibits glucose-6-phosphate isomerase (EC 5.3.1.9) activity [40] and thereby reduces carbon flux through the glycolytic pathway.

In terms of the impact of AICAR on cell proliferation, the depressed proliferation we observed did not correlate with the accumulation of ZMP alone $\left(r^{2}=0.04\right.$, data not shown), but rather was related to the fold-change in the effective adenylate ratio ([AMP]+[ZMP])/ [ATP]; $\left.\mathrm{r}^{2}=0.77\right)$. This finding underscores the need to quantitatively evaluate the impact of AICAR on the total adenylate pool before any effects of AICAR exposure are ascribed to specific activation of AMPK. The general view that AMPK is modulated by the AMP:ATP ratio rather than just by the concentration of a single nucleotide [14] is supported by our results in Figure 8A. The amount of ZMP produced by a given cell line in response to a 1 $\mathrm{mM}$ AICAR exposure varied widely from 19.9 to $68.6 \mathrm{nmol} / \mathrm{mg}$ protein. Thus, the accumulation of ZMP cannot be predicted a priori, and a detailed analysis of the specific ability of a given cell line to synthesize ZMP should be performed before any effects of the drug are attributed to ZMP accumulation.

Cellular effects of AICAR are not necessarily caused by AMPK activation and include inhibition of Complex I of the respiratory chain by ZMP directly [37] and competition with adenosine for the nucleoside transporters in the plasma membrane [17]. In addition, high levels of di- and tri-phosphorylated forms of ZMP (e.g., ZDP and ZTP) may accumulate and interact with multiple cellular processes. To substantiate the phosphorylation of AICAR to ZMP, it is important to evaluate cell extracts under the conditions used for a given experiment. Not every cell line expresses sufficiently-high adenosine kinase activity to produce the necessary concentrations of ZMP [23-25]. Furthermore, ZMP can enter the pathway of purine synthesis and may affect the concentration of several purines and purine precursors [19]. Indeed, given a sufficient exposure time to AICAR, we showed that all cell types except OMK cells accumulate substantial amounts of ZDP and ZTP (Table 1), which may have unknown physiological consequences. Thus we speculate that OMK cells would be ideal for investigating ZMP-specific effects, due to their lack of ZDP or ZTP. AICAR concentrations of above $1 \mathrm{mM}$ could be used to increase ZMP levels even further in such studies.

We found that metabolic preconditioning with AICAR increased the viability after cryopreservation of several cell lines (Fig. 6). Similar to the depression in proliferation, the fold-increase in viability was highly correlated to the fold-increase in the "effective adenylate ratio' $\left(r^{2}=0.97\right)$. We next investigated whether or not the effect of AICAR was limited to immortalized cell lines that rapidly proliferate, or if AICAR also could be used to precondition primary cells. Primary rat hepatocytes were more sensitive to AICAR exposure and responded with drops in both cellular ATP levels (Tab.1) and viability (data not shown) when exposed to $1 \mathrm{mM}$ of the drug for $24 \mathrm{~h}$. By optimizing exposure time and concentration of AICAR, a quiescent phenotype could also be induced in primary hepatocytes without the 
undesirable side effects. Exposure to $0.5 \mathrm{mM}$ AICAR and $200 \mathrm{mM} 3-\mathrm{OMG}$ for $1 \mathrm{~h}$ increased viability by $14 \%$ compared to controls without AICAR.

This study is the first to report that metabolic preconditioning with AICAR increases freeze tolerance of several cell lines and primary rat hepatocytes. Another metabolic adjustment exhibited by animal species that are naturally tolerant to environmental stress (dehydration freezing, anoxia, etc.) is the depression of oxidative phosphorylation [1-7]. Likewise, Bonnet et al. [41] presented evidence that mammalian cells with a high propensity for survival (e.g., cancer cells) direct pyruvate flux away from the TCA cycle and toward lactate production by inactivation of the pyruvate dehydrogenase complex. Thus it seems that cell stability/survival can be enhanced and apoptosis depressed by turning down oxidative phosphorylation fueled by pyruvate. Experiments to exploit this mechanism as a means to metabolically precondition cells for improved survivorship during desiccation and freezing are currently underway. Integrating such concepts of cell stasis into protocols for biostabilization may bring us closer to the exciting possibility of engineering mammalian cells and tissues that are more tolerant to long-term storage.

\section{Acknowledgments}

This study was support by National Institutes of Health grant 2-RO1-DK046270-14A1.

\section{LITERATURE CITED}

[1]. Hand SC, Hardewig I. Downregulation of cellular metabolism during environmental stress: mechanisms and implications. Annu Rev Physiol 1996;58:539-63. [PubMed: 8815808]

[2]. Podrabsky JE, Hand SC. The bioenergetics of embryonic diapause in an annual killifish, austrofundulus limnaeus. J Exp Biol 1999;202(Pt 19):2567-80. [PubMed: 10482717]

[3]. Hand, SC.; Podrabsky, JE.; Eads, BD.; Van Breukelen, F. Interrupted development in aquatic organism: ecological context and physiological mechanism. In: Atkinson, D.; Thorndyke, M., editors. Environment and Animal Development. BIOS Scientific Publishers Ltd; Oxford, UK: 2001. p. 219-234.Genes, Life Histories and Plasticity

[4]. Reynolds JA, Hand SC. Differences in isolated mitochondria are insufficient to account for respiratory depression during diapause in artemia franciscana embryos. Physiol Biochem Zool 2004;77:366-77. [PubMed: 15286911]

[5]. Hand, SC.; Hagedorn, M. New approaches for cell and animal preservation: Lessons from aquatic organisms. In: Walsh, PJ.; Smith, LE.; Fleming, LE.; Solo-Gabriele, H.; Gerwick, WH., editors. Oceans and Human Health: Risks and Remedies from the Seas. Academic Press; 2008. p. 611-629.

[6]. Podrabsky JE, Lopez JP, Fan TWM, Higashi R, Somero GN. Extreme anoxia tolerance in embryos of the annual killifish Austrofundulus limnaeus: insights from a metabolomics analysis. J Exp Biol 2007;210:2253-66. [PubMed: 17575031]

[7]. Fergusson-Kolmes L, Podrabsky JE. Differential effects of anoxia on heart rate in developmental stages of the annual killifish Austrofundulus limnaeus that differ in their tolerance of anoxia. J Exp Zool Part A Ecol Genet Physiol 2007;307:419-23.

[8]. Corton JM, Gillespie JG, Hawley SA, Hardie DG. 5-aminoimidazole-4-carboxamide ribonucleoside. A specific method for activating AMP-activated protein kinase in intact cells? Eur J Biochem 1995;229:558-65. [PubMed: 7744080]

[9]. Sullivan JE, Brocklehurst KJ, Marley AE, Carey F, Carling D, Beri RK. Inhibition of lipolysis and lipogenesis in isolated rat adipocytes with AICAR, a cell-permeable activator of AMP-activated protein kinase. FEBS Lett 1994;353:33-6. [PubMed: 7926017]

[10]. Hardie DG, Carling D, Carlson M. The AMP-activated/SNF1 protein kinase subfamily: metabolic sensors of the eukaryotic cell? Annual Review Of Biochemistry 1998;67:821-55.

[11]. Hardie DG, Hawley SA. AMP-activated protein kinase: the energy charge hypothesis revisited. Bioessays 2001;23:1112-9. [PubMed: 11746230] 
[12]. Hardie DG, Salt IP, Hawley SA, Davies SP. AMP-activated protein kinase: an ultrasensitive system for monitoring cellular energy charge. Biochem J 1999;338(Pt 3):717-22. [PubMed: 10051444]

[13]. Hardie DG. New roles for the LKB1--AMPK pathway. Curr Opin Cell Biol 2005;17:167-73. [PubMed: 15780593]

[14]. Hardie DG. AMPK: a key regulator of energy balance in the single cell and the whole organism. Int J Obes (Lond) 2008;32(Suppl 4):S7-12. [PubMed: 18719601]

[15]. Okoshi R, Ozaki T, Yamamoto H, Ando K, Koida N, Ono S, Koda T, Kamijo T, Nakagawara A, Kizaki H. Activation of AMP-activated Protein Kinase Induces p53-dependent Apoptotic Cell Death in Response to Energetic Stress. J Biol Chem 2008;283:3979-87. [PubMed: 18056705]

[16]. Kim HS, Hwang JT, Yun H, Chi SG, Lee SJ, Kang I, Yoon KS, Choe WJ, Kim SS, Ha J. Inhibition of AMP-activated Protein Kinase Sensitizes Cancer Cells to Cisplatin-induced Apoptosis via Hyper-induction of p53. J Biol Chem 2008;283:3731-42. [PubMed: 18079115]

[17]. Gadalla AE, Pearson T, Currie AJ, Dale N, Hawley SA, Sheehan M, Hirst W, Michel AD, Randall A, Hardie DG, Frenguelli BG. AICA riboside both activates AMP-activated protein kinase and competes with adenosine for the nucleoside transporter in the CA1 region of the rat hippocampus. J Neurochem 2004;88:1272-82. [PubMed: 15009683]

[18]. Vincent MF, Marangos PJ, Gruber HE, Van den Berghe G. Inhibition by AICA riboside of gluconeogenesis in isolated rat hepatocytes. Diabetes 1991;40:1259-66. [PubMed: 1657665]

[19]. Thomas CB, Meade JC, Holmes EW. Aminoimidazole carboxamide ribonucleoside toxicity: a model for study of pyrimidine starvation. J Cell Physiol 1981;107:335-44. [PubMed: 6166628]

[20]. Henin N, Vincent MF, Gruber HE, Van den Berghe G. Inhibition of fatty acid and cholesterol synthesis by stimulation of AMP-activated protein kinase. FASEB J 1995;9:541-6. [PubMed: 7737463]

[21]. Henin N, Vincent MF, Van den Berghe G. Stimulation of rat liver AMP-activated protein kinase by AMP analogues. Biochim Biophys Acta 1996;1290:197-203. [PubMed: 8645724]

[22]. Merrill GF, Kurth EJ, Hardie DG, Winder WW. AICA riboside increases AMP-activated protein kinase, fatty acid oxidation, and glucose uptake in rat muscle. Am J Physiol 1997;273:E1107-12. [PubMed: 9435525]

[23]. Javaux F, Vincent MF, Wagner DR, van den Berghe G. Cell-type specificity of inhibition of glycolysis by 5-amino-4-imidazolecarboxamide riboside. Lack of effect in rabbit cardiomyocytes and human erythrocytes, and inhibition in FTO-2B rat hepatoma cells. Biochem J 1995;305(Pt 3):913-9. [PubMed: 7848293]

[24]. Arch JR, Newsholme EA. Activities and some properties of 5'-nucleotidase, adenosine kinase and adenosine deaminase in tissues from vertebrates and invertebrates in relation to the control of the concentration and the physiological role of adenosine. Biochem J 1978;174:965-77. [PubMed: 215126]

[25]. Sullivan JE, Carey F, Carling D, Beri RK. Characterisation of 5'-AMP-activated protein kinase in human liver using specific peptide substrates and the effects of 5'-AMP analogues on enzyme activity. Biochem Biophys Res Commun 1994;200:1551-6. [PubMed: 8185610]

[26]. Seglen PO. Preparation of isolated rat liver cells. Methods Cell Biol 1976;13:29-83. [PubMed: 177845]

[27]. Berthiaume F, Moghe PV, Toner M, Yarmush ML. Effect of extracellular matrix topology on cell structure, function, and physiological responsiveness: hepatocytes cultured in a sandwich configuration. FASEB J 1996;10:1471-84. [PubMed: 8940293]

[28]. Dunn JC, Tompkins RG, Yarmush ML. Long-term in vitro function of adult hepatocytes in a collagen sandwich configuration. Biotechnol Prog 1991;7:237-45. [PubMed: 1367596]

[29]. Dunn JC, Tompkins RG, Yarmush ML. Hepatocytes in collagen sandwich: evidence for transcriptional and translational regulation. J Cell Biol 1992;116:1043-53. [PubMed: 1734019]

[30]. Peterson GL. A simplification of the protein assay method of Lowry et al. which is more generally applicable. Anal Biochem 1977;83:346-56. [PubMed: 603028]

[31]. Menze MA, Clavenna MJ, Hand SC. Depression of cell metabolism and proliferation by membrane-permeable and -impermeable modulators: role for AMP-to-ATP ratio. Am J Physiol Regul Integr Comp Physiol 2005;288:R501-10. [PubMed: 15458972] 
[32]. Gnaiger E, Kemp RB. Anaerobic metabolism in aerobic mammalian cells: information from the ratio of calorimetric heat flux and respirometric oxygen flux. Biochim Biophys Acta 1990;1016:328-32. [PubMed: 2184896]

[33]. Guan YH, Kemp RB. Detection of the changing substrate requirements of cultured animal cells by stoichiometric growth equations validated by enthalpy balances. J Biotechnol 1999;69:95114. [PubMed: 10361721]

[34]. Hand, SC. Calorimetric approaches to animal physiology and bioenergetics. In: Kemp, RB., editor. Handbook of Thermal Analysis and Calorimetry. Elsevier; Amsterdam: 1999. p. 469-510.From Molecules to Men

[35]. Doerfel, K. Beurteilung yon Analysenverfahren und Ergebnissen. Springer; Berlin Heidelberg New York: 1965.

[36]. Norris MM, Aksan A, Sugimachi K, Toner M. 3-O-methyl-D-glucose improves desiccation tolerance of keratinocytes. Tissue Eng 2006;12:1873-9. [PubMed: 16889517]

[37]. Guigas B, Taleux N, Foretz M, Detaille D, Andreelli F, Viollet B, Hue L. AMP-activated protein kinase-independent inhibition of hepatic mitochondrial oxidative phosphorylation by AICA riboside. Biochem J 2007;404:499-507. [PubMed: 17324122]

[38]. Podrabsky JE, Hand SC. Depression of protein synthesis during diapause in embryos of the annual killifish Austrofundulus limnaeus. Physiol Biochem Zool 2000;73:799-808. [PubMed: 11121353]

[39]. Jenkins AB, Furler SM, Kraegen EW. 2-deoxy-D-glucose metabolism in individual tissues of the rat in vivo. Int J Biochem 1986;18:311-8. [PubMed: 3519306]

[40]. Keenoy, B. Manuel y; Zahner, D.; Malaisse, WJ. Dissociated effects of 2-deoxy-D-glucose on D[2-3H]glucose and D-[5-3H]glucose conversion into $3 \mathrm{HOH}$ in rat erythrocytes. Biochem $\mathrm{J}$ 1992;288(Pt 2):433-8. [PubMed: 1463447]

[41]. Bonnet S, Archer SL, Allalunis-Turner J, Haromy A, Beaulieu C, Thompson R, Lee CT, Lopaschuk GD, Puttagunta L, Harry G, Hashimoto K, Porter CJ, Andrade MA, Thebaud B, Michelakis ED. A mitochondria-K+ channel axis is suppressed in cancer and its normalization promotes apoptosis and inhibits cancer growth. Cancer Cell 2007;11:37-51. [PubMed: 17222789]

[42]. Hochachka PW, Nener JC, Hoar J, Saurez RK, Hand SC. Disconnecting metabolism from adenylate control during extreme oxygen limitation. Canadian J. Zool 1993;71:1267-1270.

[43]. Wegener, G. Oxygen availability, energy metabolism, and metabolic rate in invertebrates and vertebrates. In: Acker, H., editor. Oxygen Sensing Tissues. Springer-Verlag; Berlin: 1988. p. 13-35.

[44]. Reddy DC, Davies RW. Metabolic adaptations by the leech Nephelopsis obscura during longterm anoxia and recovery. J. Exp. Zool 1993;265:224-230.

[45]. Sugimachi K, Roach KL, Rhoads DB, Tompkins RG, Toner M. Nonmetabolizable glucose compounds impart cryotolerance to primary rat hepatocytes. Tissue Eng 2006;12(3):579-588. [PubMed: 16579691] 


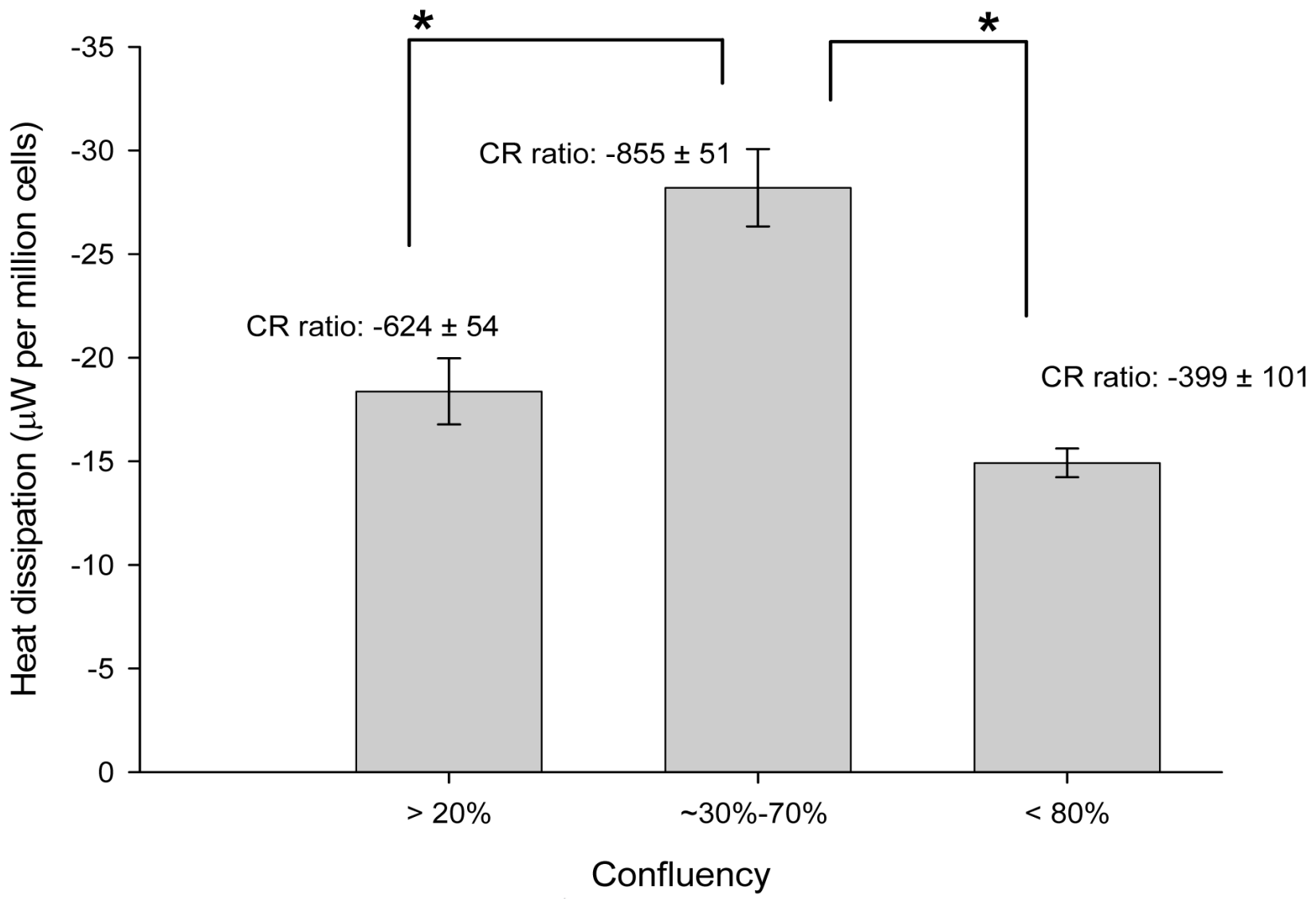

Figure 1.

Heat dissipation for mouse NIH/3T3 fibroblasts attached to micro-carrier beads as a function of cellular confluency. The calorimetric-respirometric ratios (CR ratios) are provided above each histogram bar $(n=3, \pm \mathrm{SE} ; * \mathrm{P}<0.05)$. 


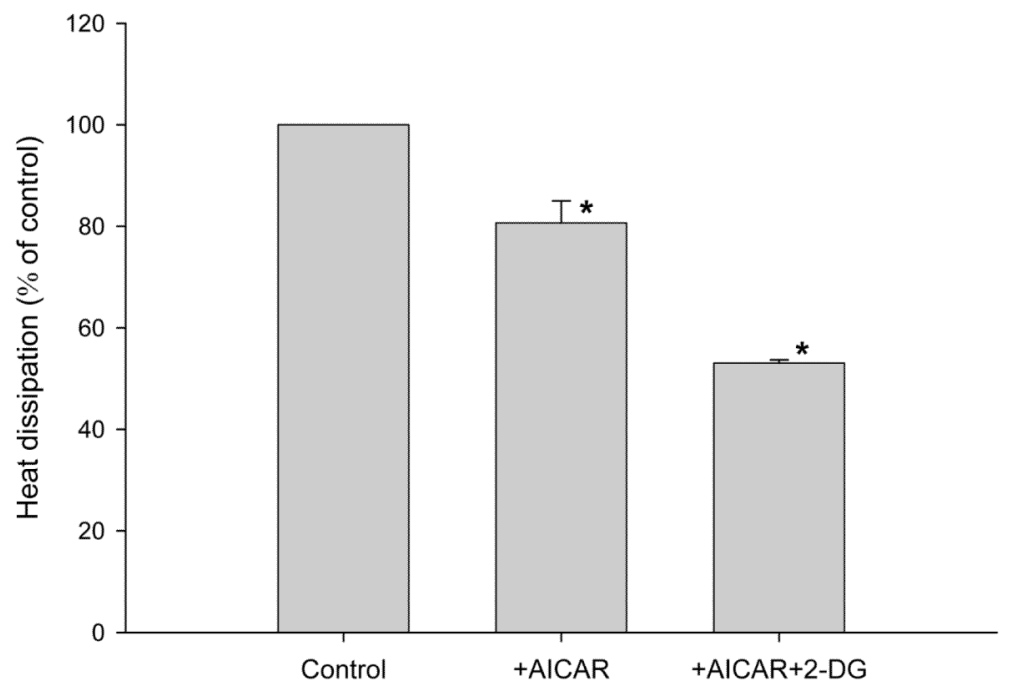

Figure 2.

Influence of metabolic modulators on heat dissipation of mouse NIH/3T3 fibroblasts. Cells were exposed for $1 \mathrm{~h}$ to $2 \mathrm{mM}$ AICAR, $20 \mathrm{mM}$ 2-deoxy-D-glucose (2-DG) or a combination of both $(n=3-5, \pm \mathrm{SE} ; * \mathrm{P}<0.05)$. 

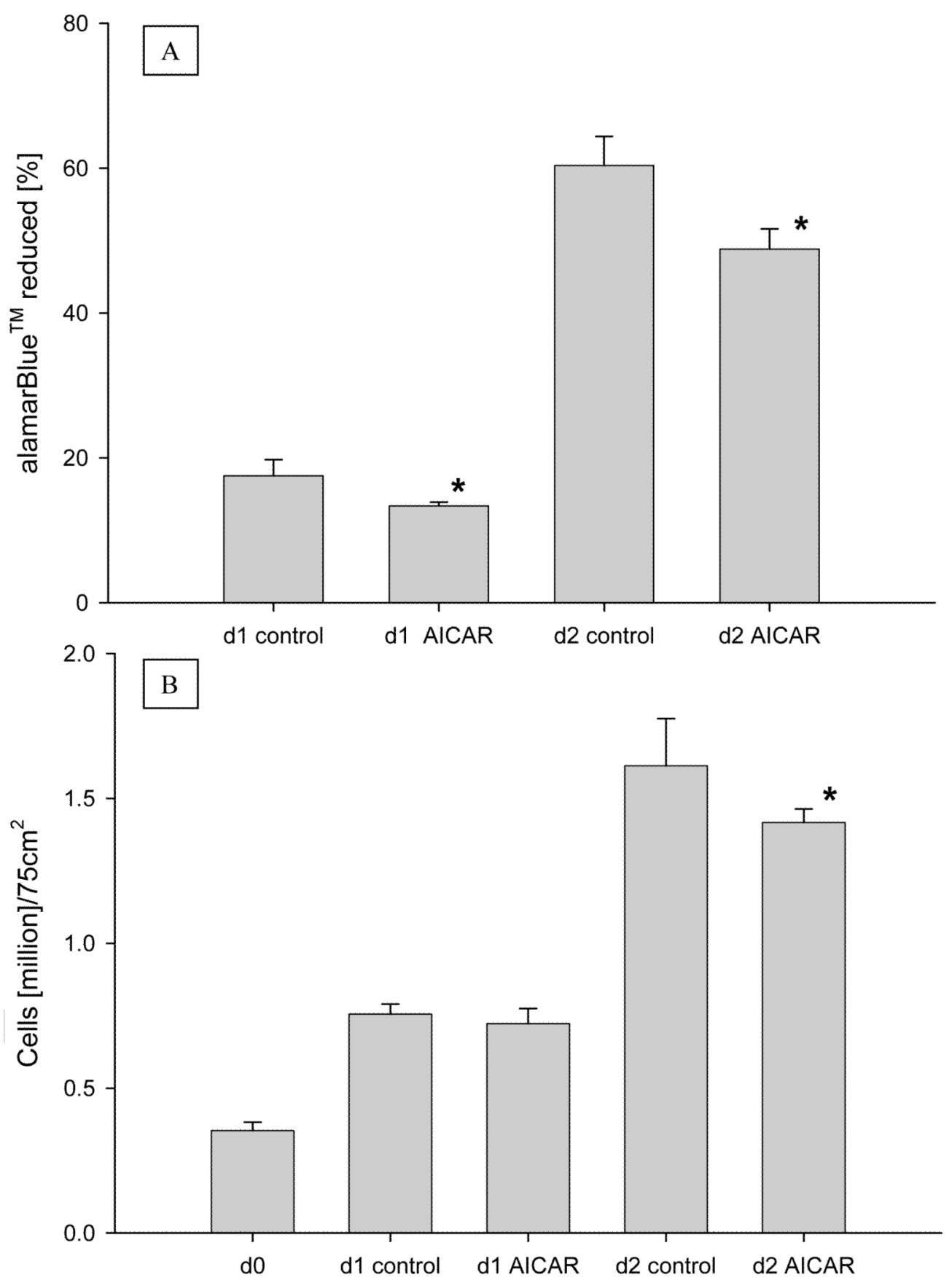

Figure 3.

Influence of $60 \mathrm{~min}$ exposure to $2 \mathrm{mM}$ AICAR on the (A) metabolic activity of mouse NIH/ $3 \mathrm{~T} 3$ fibroblasts measured by alamarBlue ${ }^{\mathrm{TM}}$ reduction and $(\mathrm{B})$ proliferation measured one day (d1) and two days (d2) after this transient exposure $(n=5-7, \pm \mathrm{SE} ; * \mathrm{P}<0.05)$. 


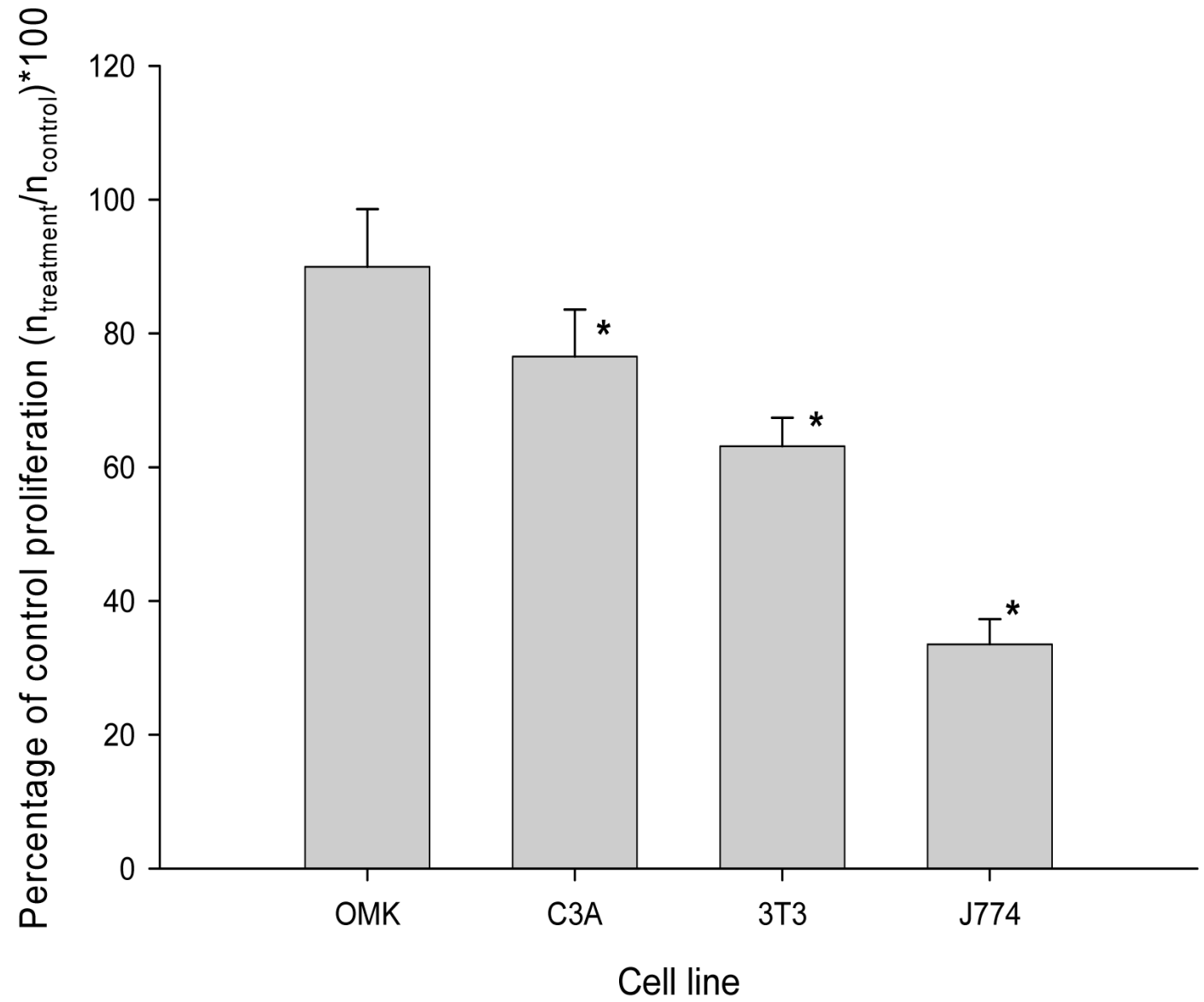

Figure 4.

Impact of $24 \mathrm{~h}$ exposure to $1 \mathrm{mM}$ AICAR on proliferation in several cell lines. $(n=5-7, \pm$ SE). OMK, owl-monkey kidney cells; C3A, HepG2/C3A hepatocellular carcinoma cells (human); 3T3, NIH/3T3 mouse fibroblasts; J774, J774 mouse macrophages. 


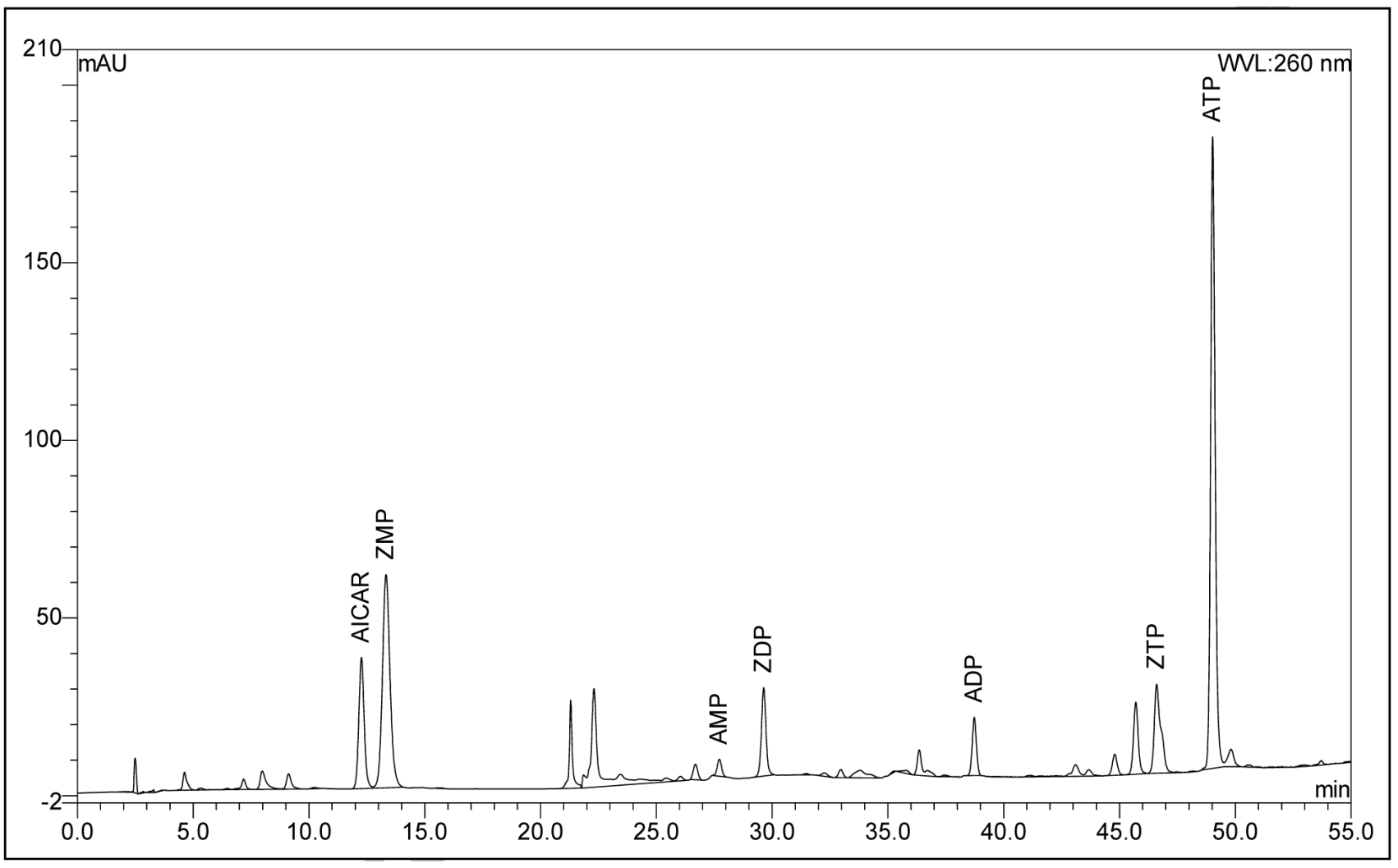

Figure 5.

Analysis of adenine nucleotide levels in mouse fibroblast cells (NIH/3T3). A representative HPLC chromatogram of a cell extract after $24 \mathrm{~h}$ incubation with $1 \mathrm{mM}$ AICAR is shown. All compounds of interest show baseline separation and accumulations of di- and triphosphorylated forms of ZMP (e.g. ZDP and ZTP) are observed. 


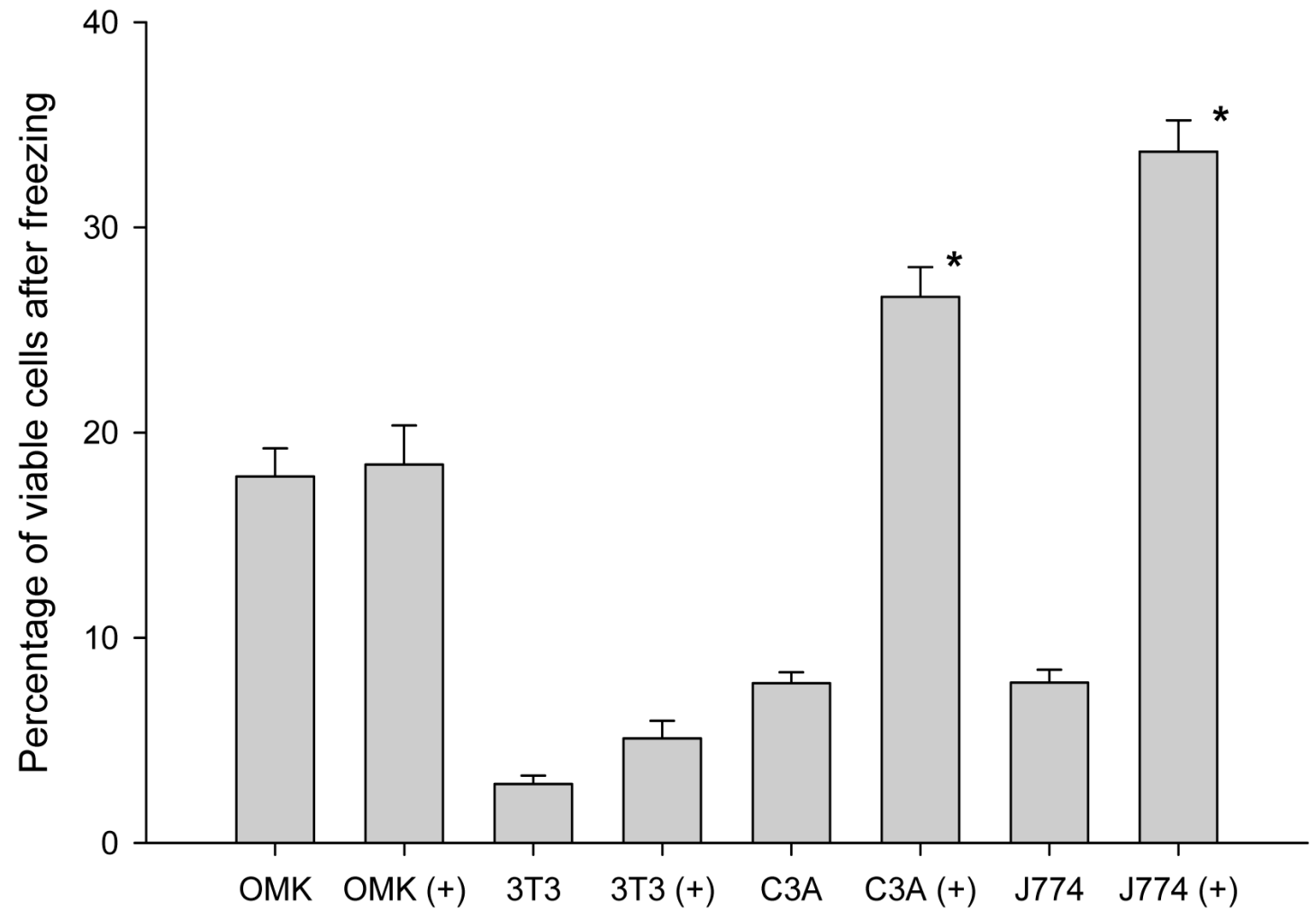

Figure 6.

Pre-exposure to AICAR ( $1 \mathrm{mM}, 24 \mathrm{~h})$ increases viability after freezing in some mammalian cell lines when frozen in presence of 3-OMG. AICAR treatment is indicated by a (+) sign after the cell line designation. Viability was assessed by trypan blue exclusion (membrane integrity) $24 \mathrm{~h}$ after plating of thawed samples and is expressed as the percentage of cells prior to freezing $(n=6-9, \pm \mathrm{SE} ; * \mathrm{P}<0.01)$. 


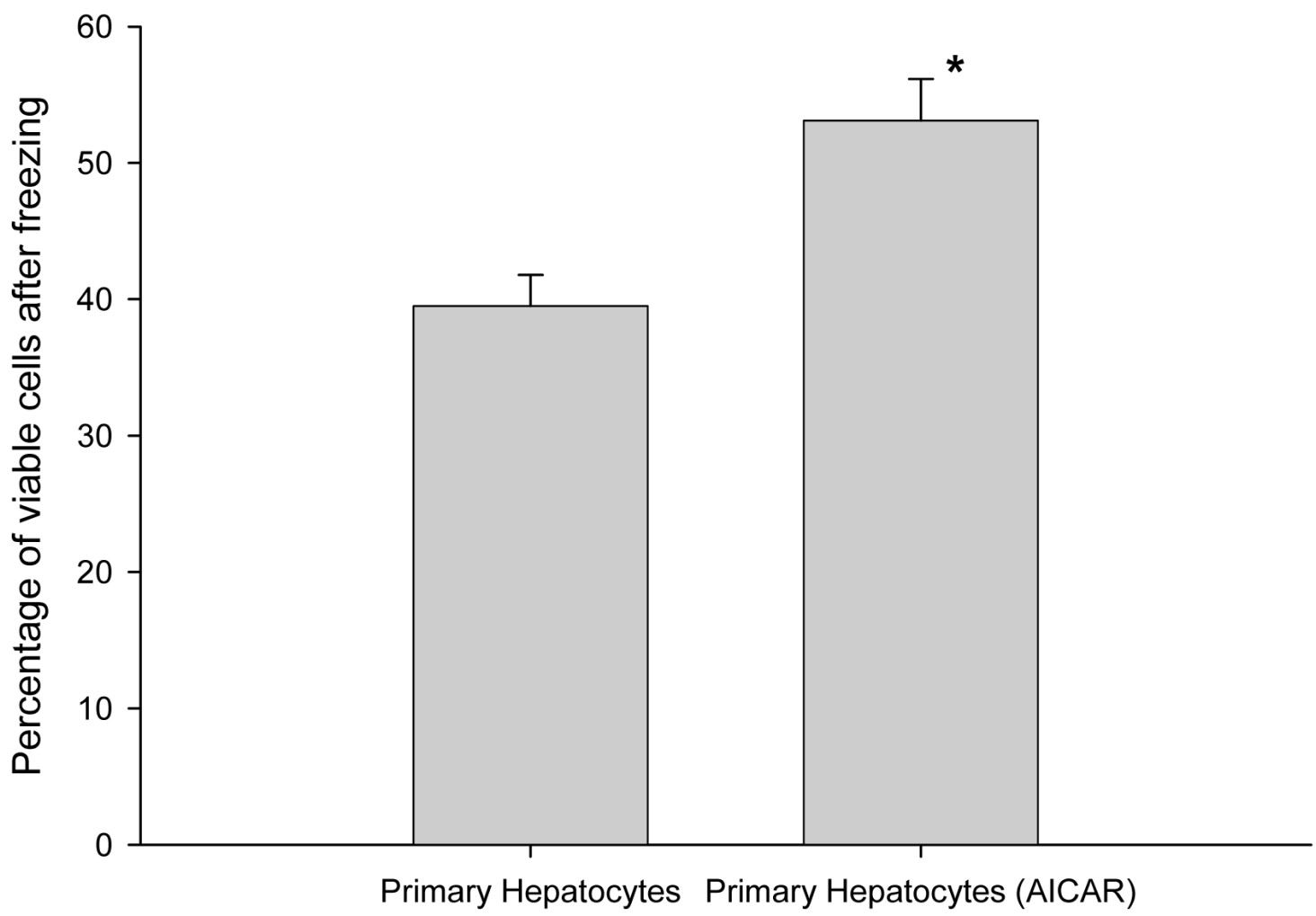

Figure 7.

Influence of $60 \mathrm{~min}$ exposure to $\operatorname{AICAR}(0.5 \mathrm{mM})$ on viability of primary hepatocytes postfreezing. Viability was assessed as trypan blue exclusion (membrane integrity) $24 \mathrm{~h}$ after plating of cells and is expressed as a percentage of the cells originally plated $(n=3, \pm \mathrm{SE}$; $* \mathrm{P}<0.05)$. 


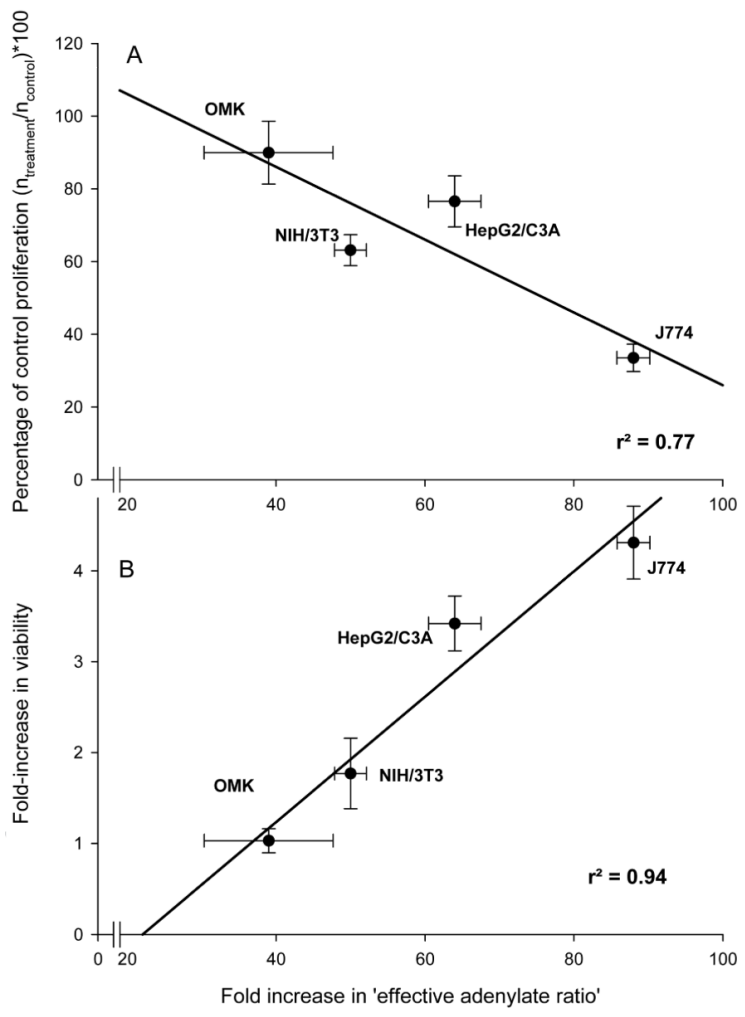

Figure 8.

(A) Depression in cell proliferation is correlated with the fold-increase in the effective adenylate ratio after AICAR treatment $([\mathrm{AMP}]+[\mathrm{ZMP}]) /[\mathrm{ATP}])$, expressed relative to the control value ([AMP]/[ATP]). (B) Fold-increase in cell viability after freezing (number of viable cells after freezing without AICAR/number of viable cells after freezing with AICAR). The effect of AICAR on viability after freezing positively correlates $\left(r^{2}=0.94\right)$ with the fold-increase in the 'effective adenylate ratio'. 


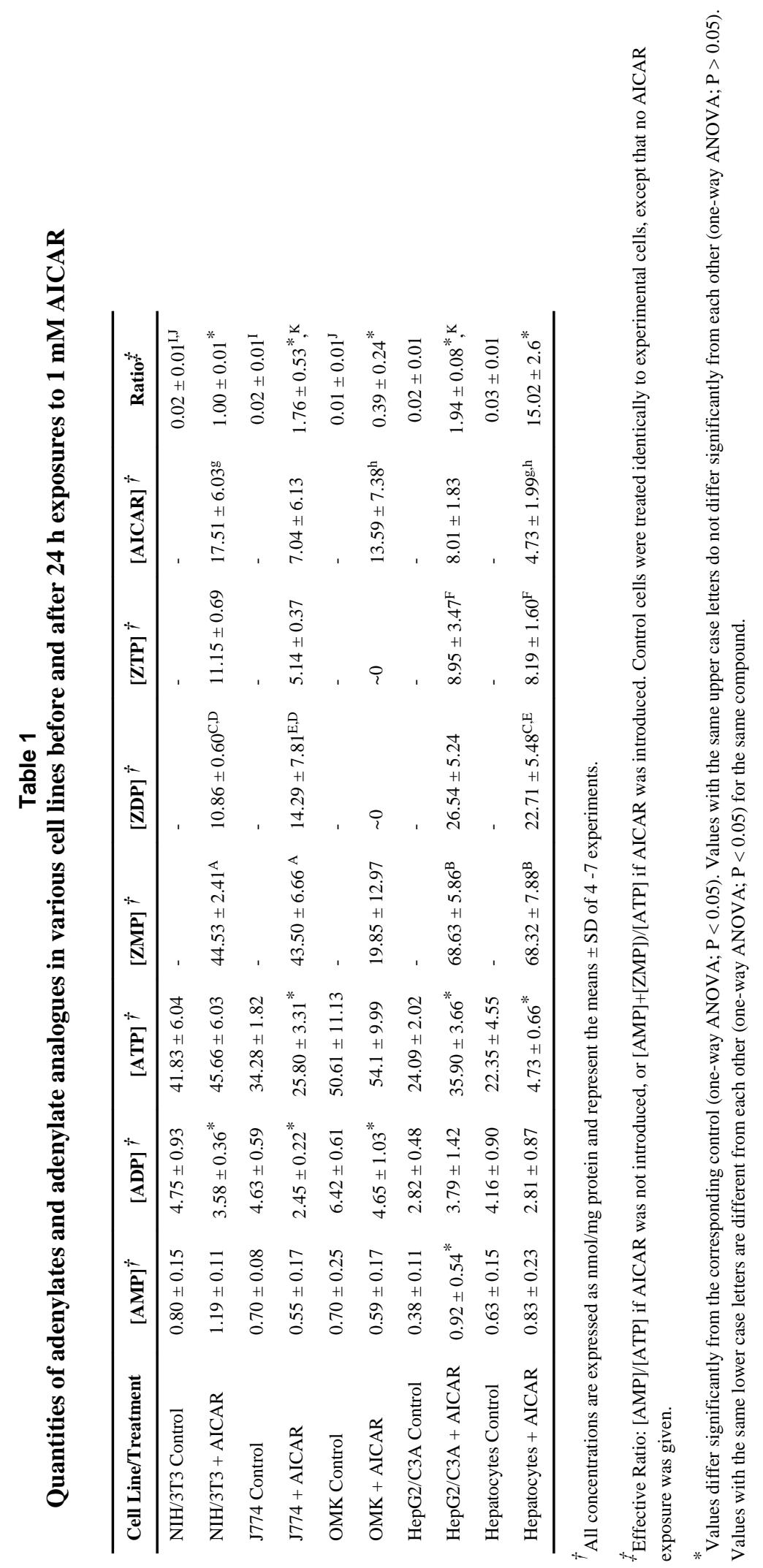

